\title{
Role of Circulating Endothelial Progenitor Cells in Micro Vascular Damage in Sickle Cell Patients
}

Bremansu Osa-Andrews ${ }^{1}$, Henry Asare-Anane ${ }^{3}$, Sylvester Yaw Oppong ${ }^{3}$, Alexander Kwadwo Nyarko ${ }^{5}$, George Kpentey ${ }^{4}$, John Tetteh ${ }^{2}$ and Ben Gyan $^{2}$

${ }^{1}$ Department of Chemistry \& Biochemistry, South Dakota State University, Brookings, South Dakota, USA

${ }^{2}$ Department of Immunology, Noguchi Memorial Institute of Medical Research (NMIMR), Legon, Ghana

${ }^{3}$ Department of Chemical Pathology, University of Ghana, Korle Bu, Ghana

${ }^{4}$ Chemical Pathology Unit, Central Laboratory, Korle Bu, Ghana

${ }^{5}$ School of Pharmacy, University of Ghana, Legon, Ghana

*Corresponding author: Bremansu Osa-Andrews, South Dakota State University, South Dakota USA, Tel: 605 688-5151; Email: Osaandrews.bremansu@sdstate.edu

Received date: Aug 08, 2017; Accepted date: Aug 31, 2017; Published date: Sep 04, 2017

Copyright: (C) 2017 Osa-Andrews B, et al. This is an open-access article distributed under the terms of the Creative Commons Attribution License, which permits unrestricted use, distribution, and reproduction in any medium, provided the original author and source are credited.

\begin{abstract}
The vascular wall participates in the pathogenesis of sickle cell disease (SCD). Circulating Endothelial progenitor cells (cEPCs) also play a key role in the vascular pathology of SCD, including the painful crisis. In previous investigations, reduced levels of cEPCs were found in conditions in which vascular injury is implicated such as myocardial infarction. The aim of this research is to study the role of CEPCs in the vascular pathology of SCD. cEPCs were enumerated using flow cytometry with the Flow Activated Cell Sorting machine (FACS). To differentiate the various genotypes-SS, SC, AS, AC and AA, Hb Electrophoresis was employed. Results showed that the median $\%$ cEPCs (CD34+/VEGF-2+) was lower in patients with SCD $[0.555(0.4,0.765)]$ than in healthy controls $[(1.08(0.87$, 1.39) $(p=0.001)$. Patients in crisis had a higher cEPCs $(0.65+0.39)$ than those in steady state $(0.59+0.28)(p=0.522)$. SS group recorded the highest mean GGT $(73.66+73.35)$. Only total cholesterol demonstrated a positive correlation $(r=0.378, p=0.00814)$ with cEPCs in subjects; a trend unseen in healthy controls. Patients' WBC, Hb and Liver enzymes- ALT, GGT, ALP showed no correlation with cEPCs. In healthy controls though, WBCs showed an inverse correlation with cEPCs $(r=-0.6293, p=0.0003)$. SCD is as much a disease of endothelial dysfunction as it is a hemoglobinopathy that triggers erythrocyte polymerization: CEPC is a surrogate bio-marker for vascular function in SCD patients. The results suggest that SCD patients have depleted CEPCs compared with healthy controls. Oxidative stress, Nitric oxide activity, loss of CD133 during homing could influence progenitor cell populations. Total cholesterol positively correlates with cEPCs. High total cholesterol could spell the onset of painful crisis. Liver enzymes are not related to cEPCs correlatively even though the liver is involved in endothelial injury in SCD patients. SS individuals tend to have a high GGT. Overall, we have shown the direct correlation between total cholesterol and cEPCs in sickle cell patients.
\end{abstract}

Keywords: Circulating endothelial progenitor cells; Sickle cell disease; White blood cells; Cholesterol

\section{Introduction}

Sickle Cell disease (SCD) is a group of chronic and lifelong genetic disorders caused by the sickle hemoglobin (HbS). In most SCD forms, the red blood cells change shape upon de-oxygenation because of polymerization of the abnormal sickle hemoglobin [1]. The average life expectancy for individuals with SCD is estimated at 42 and 48 years of age, in males and females respectively [2]. In Ghana, the situation is quite alarming. The prevalence rate as of 2005 is $2 \%$ of all births per year [3]. SCD therefore presents a major medical problem in Ghana. SCD occurs because of one of three-point mutations in a person's genetic pattern. Clinically, they give rise to hemolytic anemias of varying severity [4]. Sickle cell syndromes include sickle cell anemia (SCD-SS), hemoglobin SC (SCD-SC), and hemoglobin S sickle betaplus-thalassaemia $\left(\mathrm{Hb} \mathrm{S} / \beta_{+}\right)$and sickle beta-zero-thalassaemia $(\mathrm{Hb} \mathrm{S} /$ $ß 0)$. In the normal state, vascular endothelium presents a non-adhesive surface to circulating leukocytes and platelets while helping to prevent the clotting of blood [5]. In response to specific stimuli, however, the endothelium changes rapidly, providing signals that effectively orchestrate the recruitment of these same blood cells to sites of injury [6]. One of such endothelial cells is a group of non-leukocytic, bone marrow derived cells [7-11], called Endothelial Progenitor Cells (EPC) $[8,12,13]$. In general, EPCs are characterized by the expression of three markers, CD133, CD34, and the vascular endothelial growth factor receptor-2 (VEGFR-2). There is no known data yet on Ghanaians regarding SCD and cEPCs. Indirect evidence from previous work suggests activation of the vascular wall endothelium in SCD [14]. The aim of this research was to study the role of cEPCs in the vascular pathology of sickle cell disease. The specific objectives are to determine; a. The relationship between levels of cEPCs and SCD with regards to endothelial damage; $b$. The influence of sickle cell crisis on micro vascular damage; $c$. The association between cEPCs and clinical parameters such as $\mathrm{Hb}$, WBC, Cholesterol, liver enzymes ALT, GGT, and ALP.

\section{Materials and Methods}

The research was a hospital-based prospective study. All subjects were approved by the Ethical and Protocol Review Committee for human-subjects of the Noguchi Memorial Institute of Medical Research (NMIMR), Ghana. Sickle cell patients were voluntary blood 
Page 2 of 8

donors who attended clinic at the Center for Clinical Genetics (Sickle Cell Clinic), Korle Bu Teaching Hospital, Accra, the largest teaching hospital in Ghana. Controls for this research were enrolled from voluntary blood donors in the La community in Accra, Ghana. Adults gave their consent by signing an informed consent document approved by the Ethical and Protocol Review Committee and Institutional Review Board of the Noguchi Memorial Institute of Medical Research (NMIMR). For minors, both subjects and their parents signed different informed consent forms.

\section{Study participants}

The study participants enrolled in this study were 60 sickle cell disease patients including 39 SS and 21 SC genotypic conditions between the ages of 10 and 45 years. They presented either with acute painful crisis or were in steady state. Steady state, for this research, is defined as pain free state with no acute clinical event for at least a month before blood sampling. Twenty-nine (29) healthy individuals with either AA genotype or AC genotypes of the same age range as patients were randomly recruited for this research as controls. Three (3) individuals found to be AS were used as a study case for traits.

\section{Criteria for selection}

All study participants were recruited based on informed consent. Patients who had renal damage (serum creatinine $>2 \mathrm{mg} / \mathrm{dL}$ ), history of myocardial infarction within 6 months before blood sampling, diabetes mellitus, cerebro-vascular accident within 6 months before sampling or had been put on medications known to trigger the endothelium for least three months before sampling were excluded from the study.

\section{Blood sampling}

Five $\mathrm{ml}$ of venous blood samples was collected from each patient and aliquoted equally into two separate tubes, Na-EDTA tubes and plain tubes. The $2.5 \mathrm{ml}$ of blood samples contained in the labeled $\mathrm{Na}$ EDTA was stored immediately after collection at $4^{\circ} \mathrm{C}$ for flow cytometry. After the aliquot blood sample was taken for the flow cytometry, the remaining was used to run Full Blood Count (FBC) and then spun immediately in the centrifuge. The plasma was stored at $-200^{\circ} \mathrm{C}$. The $2.5 \mathrm{~mL}$ of blood sample contained in plain tube was also spun and the serum stored at $4^{\circ} \mathrm{C}$. The serum was then used to run the cholesterol test, creatinine, and the liver enzymes.

\section{Full blood count}

Automated blood counting machine, the Sysmex XE-2100 was used to run the FBC. The remaining $2.5 \mathrm{ml}$ blood sample after the aliquot had been taken for the FACS, was then mixed, and placed on a rack in the analyser. The machine was allowed to aspirate a very small amount of the specimen through narrow tubing. Within the tubing were sensors that counted the number of cells going through it, and also identified the type of cell.In addition to counting, measuring and analysing red blood cells, WBCs and platelets, automated haematology analysers also measured the amount of haemoglobin in the blood and within each red blood cell. The results were then printed out for review. Limitations of this method is based on the fact that certain abnormal cells in the blood may be identified incorrectly, and require manual review of the instrument's results and identifying any abnormal cells the instrument could not categorize.

\section{Sickling test for control group (screening)}

Forty $\mu \mathrm{l}$ of $2 \%$ solution of sodium metabisulfite was mixed with 20 $\mu \mathrm{l}$ of the venous blood sample from the Na-EDTA bottle on a glass slide. A cover slide was placed on the mixture and pressed with the finger to form a thin layer. A filter paper was used to blot the excess solution. The preparations were then allowed to stand for 30 minutes and then observed under a microscope using the X40 objective for the presence of the sickle cells. The test sample was compared with the controls.

\section{Hb electrophoresis to differentiate among the genotypes SS, SC, AS, AA and AC}

The procedure as reported by Dacie and Lewis [15] was used. The electrophoresis tank was prepared with Tris buffer ( $\mathrm{pH}$ 8.6). A cellulose acetate paper was used. Twenty $\mu \mathrm{l}$ of the prepared lysate was applied as a streak using a multi applicator in a $2 \mathrm{~cm}$ line $(1 / 3$ away from the cathode end of the strip). On the adjacent part of the strip, $20 \mu \mathrm{l}$ of normal and abnormal references made up of haemoglobins A, F, S and C were applied. 220 volts of electricity was then applied for 40 minutes until good separation was achieved. At the end of the separation, the membrane strip was removed from the tank with forceps. It was then stained with Ponceau $S$ and dried in a hot air oven. The test samples were then compared with the controls.

\section{Flow activated cell sorting analysis}

Hundred $\mu \mathrm{L}$ of whole peripheral blood per reaction was incubated for 15 minutes in the dark with monoclonal antibody pairs appropriately conjugated with either FITC or PE to endothelial cell markers: CD34/VEGFR-2, CD133/CD34 and CD133/CD34. Three separate aliquots of cells incubated with or without CD15-PE or CD15FITC were used as controls to set gating parameters. After incubation, RBCs were lysed with FACS lysis solution and then the samples washed with FACS flow. The cells were immediately analysed or fixed in $1 \%$ paraformaldehyde and stored in the dark at $4^{\circ} \mathrm{C}$. Stored samples were analysed within 2 weeks. The \% cEPCs and absolute number (based upon the WBC count) were determined for each subject.

\section{The staining process}

1. Six falcon tubes per subject were labelled for identification number of subject and tube number. The process was repeated for the rest of the number of samples available.

2. Reagent Volumes were prepared as shown in Table 1.

\begin{tabular}{|l|l|l|l|l|}
\hline Tube No & Monoclonal Ab FITC & Volume & Monoclonal Ab PE & Volume \\
\hline 1 & No MAb & Nil & No MAb & Nil \\
\hline 2 & CD15 & $5 \mu \mathrm{l}$ & No MAb & Nil \\
\hline 3 & No MAb & Nil & CD15PE & $5 \mu \mathrm{l}$ \\
\hline 4 & No MAb & Nil & No MAb & Nil \\
\hline 5 & CD34 FITC & $5 \mu \mathrm{l}$ & VEGF-2 PE & $5 \mu \mathrm{l}$ \\
\hline 6 & CD34 FITC & $5 \mu \mathrm{l}$ & CD133 PE & $5 \mu \mathrm{l}$ \\
\hline
\end{tabular}

Table 1: Volumes of reagents and samples used in the flow cytometry. MAb-Monoclonal Antibody 
Page 3 of 8

As demonstrated in table 1 above, the prescribed volume of monoclonal antibody was first added, followed by the volume of blood with or without antibody. It is important to note that tubes 1 and 4 did not contain any monoclonal antibodies, whereas tubes 2 and 3 contained only a single monoclonal antibody and tubes 5 and 6 had monoclonal antibodies.

3. Fifty $\mu \mathrm{L}$ of EDTA blood was added to test tubes $1,2,3,5,6$. No blood was put in 4 . The tubes were then vortexed for 10 seconds. The tubes were then placed in a rack and incubated in a dark room for 20 minutes.

4. After incubation, $2 \mathrm{ml} 1 \mathrm{xFACS}$ lysing solution was added to tubes $1,2,3,5,6$ and vortexed again for 10 seconds.

\section{Estimation of total cholesterol}

\section{Chemicals}

Reagent A: PIPES $35 \mathrm{mmol} / \mathrm{L}$, Sodium Cholate $0.5 \mathrm{mmol} / \mathrm{L}$, Phenol $28 \mathrm{mmol} / \mathrm{L}, \mathrm{pH}=7.0$., Reagent $B$ : Cholesterol esterase $>5 \mu \mathrm{mol} / \mathrm{ml}$, Cholesterol oxidase $>2 \mu \mathrm{mol} / \mathrm{ml}$, Peroxidase $>20 \mu \mathrm{mol} / \mathrm{L}, \quad 4-$ Aminoantipyrine $12.2 \mathrm{mmol} / \mathrm{L}$, Cholesterol Standard: $200 \mathrm{mg} / \mathrm{dl}$

\section{Procedure}

Reagent Preparation was done by transferring the contents of Reagent B bottle were into the bottle containing Reagent A and was thoroughly mixed. Three test tubes were labeled as ST (standard), S (sample), and B (blank). $10 \mu \mathrm{l}$ of cholesterol standard was pipetted into tube ST. Ten $\mu$ l of serum was pipetted into tube S, $10 \mu \mathrm{l}$ of distilled water was also pipetted into tube $\mathrm{B}$. One $\mathrm{ml}$ of working reagent was added to the contents of the three tubes and well mixed. They were incubated for 10 minutes at room temperature. The absorbance (A) of the standard and samples were measured at $500 \mathrm{~nm}$ against the blank by using the BTS semi-automated spectrophotometer. Concentration of the cholesterol was calculated using equation 1 below.

\section{$\frac{\text { Sample Absorbance } \mathrm{x} \text { cholesterol standard }}{\text { Standard Absorbance }}(\mathrm{mmol} / \mathrm{L})(1)$}

\section{Estimation of ALT}

\section{Chemicals}

Reagent A: Tris $110 \mathrm{mmol} / \mathrm{L}, \mathrm{L}$-alanine $550 \mathrm{mmol} / \mathrm{L}, \mathrm{pH}=7.3$., Reagent B: 2-oxoglutarate $16.5 \mathrm{mmol} / \mathrm{L}, \mathrm{NADH} 0.2 \mathrm{mmol} / \mathrm{L}$, Lactate dehydrogenase $>1350 \mu \mathrm{mol} / \mathrm{L}$ Reagent $\mathrm{C}$ : Pyrodoxal phosphate 5 $\mathrm{mmol} / \mathrm{L}$. working reagent: Reagent $\mathrm{B}$ was mixed with the entire content of Reagent A. Five $\mathrm{ml}$ of this mixed reagent was again mixed with 0.1 $\mathrm{ml}$ of Reagent $\mathrm{C}$. This formed the actual working reagent.

\section{Procedure}

Reagent preparation was performed by mixing Reagent B was with the entire content of Reagent $\mathrm{A}$. Five $\mathrm{ml}$ of this mixed reagent was again mixed with $0.1 \mathrm{ml}$ of Reagent $\mathrm{C}$. This formed the actual working reagent. One $\mathrm{ml}$ of the working reagent and $50 \mu \mathrm{l}$ of sample were pipetted into a cuvette. The content was well mixed and the cuvette inserted into the BTS spectrophotometer. After one to two minutes, the initial absorbance was read at a wavelength of $340 \mathrm{~nm}$ and recorded; then replicated at one-minute intervals for three minutes. The differences between consecutive absorbances were calculated and the average absorbance difference per minute was recorded.
Calculation: change in absorbance per minute $\times 3333 \mu \mathrm{mol} / \mathrm{L}$

\section{Measurement of ALP}

\section{Chemicals}

Reagent A: Diethanolamine $1.0 \mathrm{~mol} / \mathrm{L}$, Magnesium chloride 0.5 $\mathrm{mmol} / \mathrm{L}, \mathrm{pH}=9.8$. Reagent $\mathrm{B}$ : 4-Nitrophenylphosphate $12 \mathrm{mmol} / \mathrm{L}$ (in tablets).

\section{Procedure}

One tablet of Reagent $B$ was dissolved in $20 \mathrm{ml}$ of Reagent $A$ to prepare the working reagent. One (1.0) $\mathrm{ml}$ of the working reagent and $20 \mu \mathrm{l}$ of sample were pipetted into the cuvette and thoroughly mixed. The cuvette was immediately inserted into the spectrophotometer and initial absorbance recorded at one-minute intervals for three minutes at the wavelength of $405 \mathrm{~nm}$. The differences between consecutive absorbances were calculated, and the average absorbance difference per minute recorded.

Calculations: Change in absorbance per minute $\times 2764 \mu \mathrm{mol} / \mathrm{L}$.

\section{Measurement of GGT}

\section{Chemicals}

Reagent A: Glycyglycine 165 mmol/L, pH 7.9, Reagent B: Gammaglutamyl-3-carboxy-4-nitroanalide, $6.6 \mathrm{mmol} / \mathrm{L}$ after reconstitution.

\section{Procedure}

The contents of Reagent B vial were reconstituted with $15 \mathrm{ml}$ of Reagent A by a gentle swirl making up the working reagent. One (1.0) $\mathrm{ml}$ of working reagent and $100 \mu \mathrm{l}$ of sample were pipetted into a cuvette. This was inserted into the semi-automated spectrophotometer. Initial absorbance was recorded at one minute and after three minutes intervals.

The difference between consecutive absorbances and the average absorbance difference per minute was calculated. The wavelength at which readings were done was $410 \mathrm{~nm}$.

Calculation: $\Delta \mathrm{A} \times 1391 \mu \mathrm{mol} / \mathrm{L}$ where $\Delta \mathrm{A}$ is the change in absorbance.

\section{Measurement of Creatinine}

\section{Chemicals}

Reagent A: Picric acid $25 \mathrm{mmol} / \mathrm{L}$ Reagent B: Sodium hydroxide 0.2 $\mathrm{mmol} / \mathrm{L}$, Creatinine standard: $2 \mathrm{mg} / \mathrm{dl}$

\section{Procedure}

Equal volumes of Reagent A and B were mixed thoroughly and this made formed the working reagent. The spectrophotometer was zeroed with distilled water. One (1.0) $\mathrm{ml}$ of the working reagent was pipetted into the pre-warmed cuvette which was inserted into the photometer. Hundred (100) $\mu \mathrm{l}$ of standard or sample was added to the working reagent. The absorbance (A) was read at $500 \mathrm{~nm}$ and recorded after thirty seconds (A1) and after ninety seconds (A2).

$$
\text { Calculation: } \frac{(\mathrm{A} 2-\mathrm{A} 1) \times 1 / 2}{(A 2-A 1) S T} \mathrm{mg} / \mathrm{dl} \text { Statistical analysis }
$$


Citation: Osa-Andrews B, Asare-Anane H, Oppong SY, Nyarko AK, Kpentey G, et al. (2017) Role of Circulating Endothelial Progenitor Cells in Micro Vascular Damage in Sickle Cell Patients. J Blood Disord Transfus 8: 389. doi:10.4172/2155-9864.1000389

Page 4 of 8

Normally distributed data was expressed as mean + SD. Data was always represented as median $(25 \%, 75 \%)$ when normality test failed. The Sigma Stats version 3.1 was used for most of the statistical work. Mann-Whitney Rank Sum Test was used to verify results.

The unpaired and paired student t-test was used to evaluate significant differences between two means. For multiple comparisons, one-way analysis of variance was used with the post hoc analysis to confirm significance between groups.

All p-values less than 0.05 were considered significant. Spearman Rank Order Correlation was used to find the association between two continuous variables. For pairs with $\mathrm{P}$ values greater than 0.050 , there was no significant relationship between the two variables. Data obtained was tabulated and the chi-square test for hypothesis was employed for significant ' $\mathrm{p}$ ' values $(\mathrm{p}<0.05)$.

\section{Results}

\section{Baseline characteristics of sub-groups of study participants}

In all, the study participants were 60 cases and 29 controls. These included 46 males and 43 females. All study participants and healthy controls were categorized into five (5) sub-groups; SS, SC, AS, AA, AC. All the sub-groups considered in this work were characterized as per other clinical parameters.

The various baseline characteristics considered were, age, gender, white blood cells count, and hemoglobin level. Generally, the WBC counts were highest in particularly the $\mathrm{Hb}$ SS group $(13.31+4.18)$ than in the rest of the other sub-groups $(\mathrm{p} \leq 0.001)$ with the AA sub-group with the least WBCs count $(6.18+2.10)$. Again, the SS genotype recorded the least hemoglobin level $(8.43+1.63, \mathrm{p} \leq 0.001)$, while the AS group had the highest $\mathrm{Hb}$ level $(13.56+0.91) \mathrm{p} \leq 0.001)$ (Table 2).

\begin{tabular}{|l|l|l|l|l|l|}
\hline & SS & SC & AS & AA & AC \\
\hline $\mathbf{N}$ & 39 & 21 & 3 & 20 & 6 \\
\hline Age (years) & $\begin{array}{l}24.08+7.9 \\
8\end{array}$ & $\begin{array}{l}24.47+6.6 \\
5\end{array}$ & $\begin{array}{l}21.67+5.0 \\
3\end{array}$ & $\begin{array}{l}28.95+11.7 \\
7\end{array}$ & $\begin{array}{l}21.83+11.4 \\
4\end{array}$ \\
\hline Male (\%) & $21(53 \%)$ & $8(39 \%)$ & $2(66 \%)$ & $11(55 \%)$ & $4(66 \%)$ \\
\hline $\begin{array}{l}\text { WBC } \\
\mathbf{1 0} / \text { lul }\end{array}$ & $\begin{array}{l}13.31+4.1 \\
8\end{array}$ & $8.31+3.34$ & $7.23+3.04$ & $6.18+2.10$ & $6.78+1.09$ \\
\hline Hb-g/dl & $8.43+1.63$ & $\begin{array}{l}11.23+1.4 \\
6\end{array}$ & $\begin{array}{l}13.56+0.9 \\
1\end{array}$ & $12.94+1.56$ & $3.42+1.34$ \\
\hline
\end{tabular}

Values for age, WBC count and $\mathrm{Hb}$ levels were calculated as mean \pm standard deviation

Table 2: Characteristics of patients and control sub-groups.

\section{Cholesterol, Creatinine, and Liver enzymes}

The SS group had the least mean total cholesterol level $(3.07+0.69)$ $(\mathrm{P} \leq 0.001)$ (Table 2). The difference in mean GGT of sub groups was significant $(\mathrm{P} \leq 0.001)$. Again, the $\mathrm{SS}$ group had the highest mean GGT $(73.66+73.35) \quad(\mathrm{P} \leq 0.001)$ which was also higher than the documentedreferencerange(13-58) $\leq \mu \mathrm{mol} / \mathrm{L}$. Percentage cEPCs of sickle cell patients and healthy individuals. The median \%cEPCs (CD34+/VEGF-2+) was lower in patients with SCD [0.55(0.4-0.765)] than in healthy controls $(1.08(0.87-1.39)](\mathrm{P} \leq 0.001)$ (Figure 1$)$. The median \%cEPCs (CD34+/CD133+) was also lower in cases $(0.3(0.205-0.425)(\mathrm{P} \leq 0.001)$ than in healthy controls $[0.66(0.46,0.89)]$ $(\mathrm{P} \leq 0.001)$.

\begin{tabular}{|c|c|c|c|c|c|}
\hline \multicolumn{6}{|c|}{ Patient and Control group } \\
\hline & sS & sc & AS & AA & $A C$ \\
\hline $\begin{array}{l}\text { T-CHOL- } \\
\mathrm{mmol} / \mathrm{L}\end{array}$ & $3.07+0.69$ & $3.46+0.86$ & $4.3+0.26$ & $4.78+1.21$ & $5.08+1.17$ \\
\hline $\begin{array}{l}\text { CREAT- } \\
\mu \mathrm{mol} / \mathrm{L}\end{array}$ & $\begin{array}{l}63.14+19.1 \\
3\end{array}$ & $\begin{array}{l}73.4+14.2 \\
1\end{array}$ & $\begin{array}{l}88.00+14 \\
00\end{array}$ & $\begin{array}{l}86.30+12 \\
36\end{array}$ & $75.67+6.06$ \\
\hline ALT-U/L & $\begin{array}{l}24.86+40.2 \\
7\end{array}$ & $\begin{array}{l}16.50+8.9 \\
7\end{array}$ & $\begin{array}{l}30.00+26 \\
19\end{array}$ & $\begin{array}{l}19.35+11 \\
91\end{array}$ & $17.00+1.15$ \\
\hline GGT-U/L & $\begin{array}{l}73.36+73.3 \\
5\end{array}$ & $\begin{array}{l}35.20+24 \\
28\end{array}$ & $\begin{array}{l}22.67+2.8 \\
7\end{array}$ & $\begin{array}{l}50.05+40 \\
36\end{array}$ & $\begin{array}{l}27.17+12.2 \\
3\end{array}$ \\
\hline ALP-U/L & $\begin{array}{l}119.07+73 \\
02\end{array}$ & $\begin{array}{l}74.85+28 \\
03\end{array}$ & $\begin{array}{l}98.33+50 \\
08\end{array}$ & $\begin{array}{l}80.10+30 \\
59\end{array}$ & $\begin{array}{l}122.17+40 \\
21\end{array}$ \\
\hline \multicolumn{6}{|c|}{$\begin{array}{l}\text { T-CHOL: Total Cholesterol; CREAT: Creatinine; ALT: Alanine Transaminase; } \\
\text { GGT: Gamma Glutamyl Transpeptidase; ALP: Alkaline Phosphatase. All values } \\
\text { were calculated as mean } \pm \text { standard deviation. }\end{array}$} \\
\hline
\end{tabular}

Table 3: Comparison of mean cholesterol, creatinine, and liver enzymes of sub groups.

\section{Crises versus steady state}

In order to determine the role of EPCs in the severity of the SCD, the data obtained was divided further into two groups; Crisis and steady state. Crises group were those patients who suffered joint and/or back pains within the last month before blood sampling. Steady states were those who experienced no painful symptoms. EPCs (\%CD34+/ VEGF-2+), were significantly higher in crisis $(0.65+0.39)$ than steady state patients $(0.59+0.28 . \mathrm{p}=0.0522)$ (Figure 3$)$. The difference in the mean \%EPCs between the two groups (\%CD34+/CD133+) was also not significant; crisis $(0.33+0.18)$ and steady state $0.31+0.13(\mathrm{p}=0.522)$, (Figure 2).

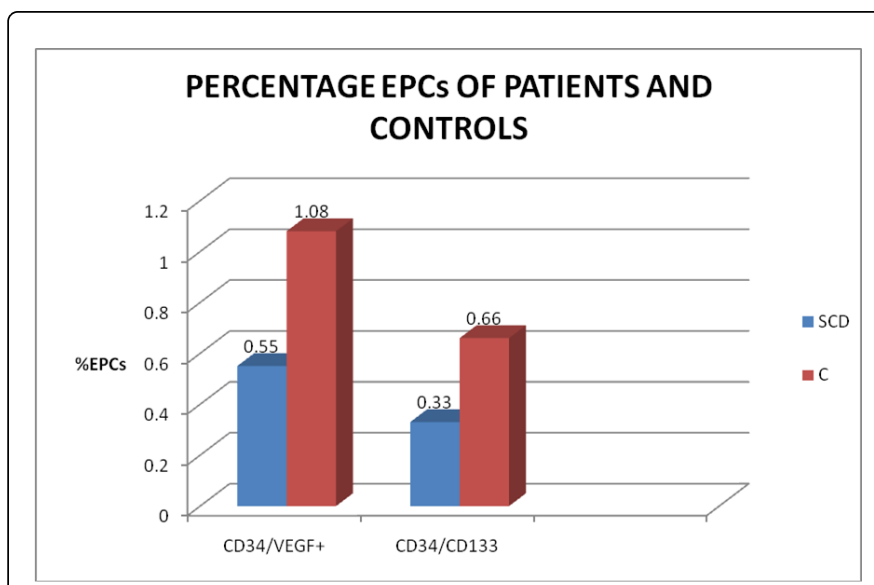

Figure 1: Median Percentage cEPCs between sickle cell patients and healthy controls. CD34+/VEGF-2+ represents EPCs using CD34+/ VEGF-2+ as antibody, CD34+/CD133+ represents EPCs using CD34+/CD133+ as antibody. SCD: Sickle Cell Disease Group: C: Healthy Control. 
Citation: Osa-Andrews B, Asare-Anane H, Oppong SY, Nyarko AK, Kpentey G, et al. (2017) Role of Circulating Endothelial Progenitor Cells in Micro Vascular Damage in Sickle Cell Patients. J Blood Disord Transfus 8: 389. doi:10.4172/2155-9864.1000389

Page 5 of 8

\section{Painful crisis and sub-groups}

SCD non-painful crisis group had the least median \%cEPC $[0.500(0.370,0.723)](\mathrm{P} \leq 0.001)$ compared to healthy individuals with AC genotype which recorded the highest $[1.35(1.02,1.46)](\mathrm{P} \leq 0.001)$ (Figure 3).

\section{Percentage EPCs and total Cholesterol}

Results showed a strong correlation $(\mathrm{r}=0.378, \mathrm{p}=0.00814)$ between cEPCs and total cholesterol in the sickle cell patients group (Table 4).

However, there was no correlation between cEPCs and total Cholesterol within the healthy control group $(\mathrm{r}=0.06908, \mathrm{p}=0.5917)$ (Table 5).

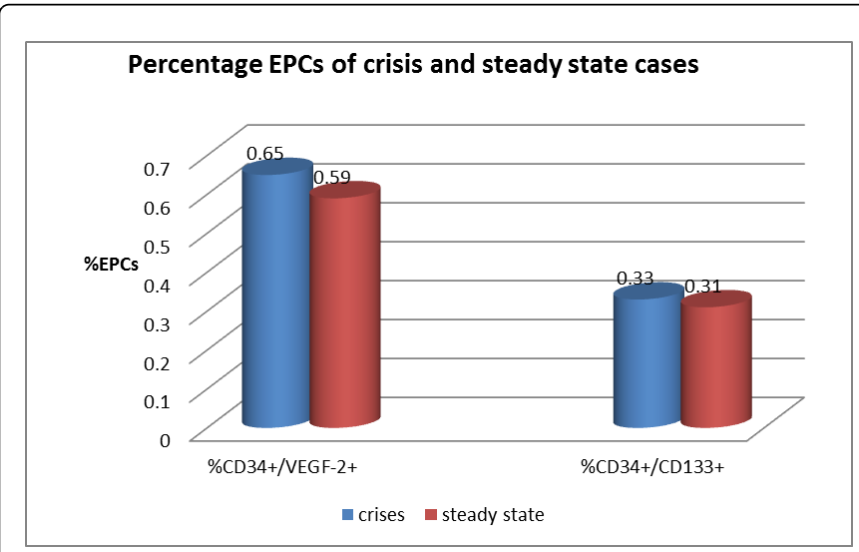

Figure 2: Mean percentage EPCs between crisis and steady state cases

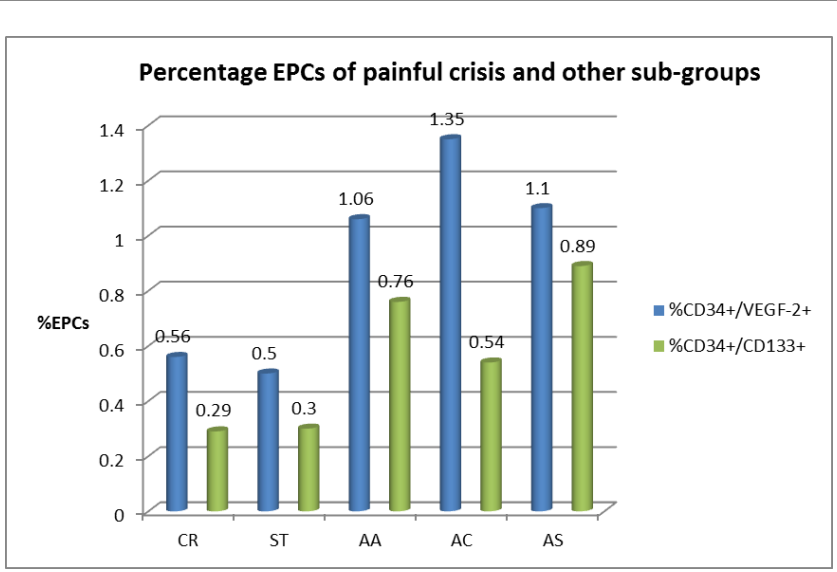

Figure 3: Median Percentage EPCs of sub-groups and disease states, $\mathrm{ST}=$ patients in steady state, $\mathrm{CR}=$ patients who had crisis

\section{Percentage EPCs and hemoglobin level}

There was no significant correlation between percentage EPCs and Hemoglobin levels in both patients $(\mathrm{r}=0.190, \mathrm{p}=0.195)$ (Table 4) and healthy control group $(\mathrm{r}=-0.04969, \mathrm{p}=0.798)$ (Table 5).

\begin{tabular}{|l|l|l|l|l|l|l|}
\hline EPCs & T- Chol & Hb & WBC & ALT & GGT & ALP \\
\hline $\mathbf{r}$ & 0.378 & 0.19 & -0.266 & 0.1921 & -0.02117 & -0.01946 \\
\hline $\mathbf{p}$ & 0.008 & 0.195 & 0.068 & 0.1813 & 0.884 & 0.8933 \\
\hline
\end{tabular}

T-Chol: Total Cholesterol; Hb: Hemoglobin; WBC: White Blood Cells; ALT: Alanine Transaminase; GGT: Gamma Glutamate Transaminase; ALP: Alkaline Phosphatase

Table 4: Association between EPCs of subjects and their Total Cholesterol, Hemoglobin, White blood cells, Alanine Transaminase, Gamma Glutamyl Transpeptidase, and Alkaline Phosphatase.

\begin{tabular}{|l|l|l|l|l|l|l|}
\hline EPCs & T- Chol & Hb & WBC & ALT & GGT & ALP \\
\hline $\mathbf{r}$ & 0.06908 & -0.04969 & -0.6293 & 0.1794 & 0.03814 & 0.102 \\
\hline $\mathbf{p}$ & 0.5917 & 0.798 & 0.0003 & 0.3428 & 0.8414 & 0.5917 \\
\hline
\end{tabular}

T-Chol: Total Cholesterol; Hb: Hemoglobin; WBC: White Blood Cells; ALT: Alanine Transaminase; GGT: Gamma Glutamate Transaminase; ALP: Alkaline Phosphatase

Table 5: Association between EPCs of controls and their Total Cholesterol, Hemoglobin, White blood cells, Alanine Transaminase, Gamma Glutamyl Transpeptidase, and Alkaline Phosphatase.

\section{Percentage EPCs and White Blood Cell count}

There was no significant relationship between percentage late cEPCs and White Blood Cells counts in sickle cell patients. $(r=-0.266$, $\mathrm{p}=0.0679$ ), (Table 4). However, there was a strong inverse correlation in healthy controls $(\mathrm{r}=-0.6293, \mathrm{p}=0.0003)$, (Table 5).

\section{Percentage EPCs and ALT}

Results of correlation analysis did not demonstrate any significant relationship between percentage EPCs and ALT in both subjects $(\mathrm{r}=0.1921, \mathrm{p}=0.1813)$, (Table 4) and healthy controls ( $\mathrm{r}=0.1794$, $\mathrm{p}=0.3428$ ), (Table 5).

\section{Percentage EPCs and GGT}

Results of correlation analysis did not demonstrate any significant relationship between percentage EPCs and GGT in both subjects $(\mathrm{r}=-0.02117, \mathrm{P}=0.884)$ (Table 4) and healthy controls $(\mathrm{r}=0.03814$, $\mathrm{P}=0.8414$ ), (Table 5).

\section{Percentage EPCs and ALP}

There was no significant correlation between EPCs and ALP in both subjects ( $\mathrm{r}=0.01946, \mathrm{p}=0.8933)$, (Table 4) and healthy controls $(\mathrm{r}=0.102, \mathrm{p}=0.5917)$, (Table 5).

\section{Discussion}

Endothelial damage eventually represents a balance between the extent of damage and the capacity for repair. Various reports clearly show that sickle cell disease triggers endothelial insult. Sickle cell disease (SCD) is as much a disease of endothelial dysfunction as it is a hemoglobinopathy that triggers erythrocyte polymerization.

Mal-functional endothelium therefore, reflects this progressive damage. The hypothesis of this research spells out that Circulating 
Endothelial Progenitor Cells participate in the regeneration of injured endothelium and of ischemic organs.

There is lack of full grasp of the actual mechanism by which vascular repair proceeds. No published data describe the life time of EPCs in vivo under physiological and pathological conditions [16].

Data regarding the number of EPCs in peripheral circulation of healthy adults are scant [16]. In all, the number of EPCs in healthy individuals is low [17]. Results from table 2 indicate a further depletion of \%EPCs in sickle cell disease relative to healthy controls. Low levels of cEPCs in patients with SCD could possibly be a byproduct of a host of underlying mechanisms. Any condition that opposes EPC mobilization from bone marrow would directly or indirectly lead to diminished EPCs in peripheral blood.

Mobilization of EPCs from the bone marrow into peripheral blood is major to their function at sites of injury. Other conditions that disturb the half-life of the immature EPCs could also be responsible for exhaustion. Oxidative stress, Nitric oxide (NO) activity, and other physiological processes could influence progenitor cell populations.

NO for instance, is a free radical and a potent vasodilator. It inhibits platelet aggregation and regulates vascular homeostasis. Reduction in bio-available NO predisposes to increased vascular tone (narrowing) and platelet aggregation [18].

Impaired NO bioavailability represents the central feature of endothelial dysfunction, and is a common denominator in the pathogenesis of vasculopathy in SCD [19].

Another explanation to the low percentage EPC in Sickle cell disease is that; continuous endothelial injury or dysfunction leads to an eventual exhaustion of a presumed finite supply of EPCs.

These results are consistent with what has been observed in patients with muscular dystrophy [20]. Owing to the continuous cycles of damage and repair associated with the underlying diathesis, patients with muscular dystrophy, over time, exhaust their supply of resident progenitor cells.

Similarly, repeated cycles of crisis and steady states in the life time of a Sickle cell disease patient could consequently result in such exhaustion. Low EPCs of levels in patients with SCD is in agreement with a review study published by [19]. Claudia reported that a study conducted on 24 patients who had Sickle cell disease with high plasma sVCAM-1 levels showed low numbers of circulating EPCs compared to 10 African-American control subjects, using a colony-forming assay. Finally, the low EPC patients have higher pulmonary pressures.

The study concluded that circulating EPC counts appear to be lower in SCD patients with vasculopathy than the general population, and the low counts may correlate with endothelial dysfunction [19]. In view of that study and the trend of our results, it may follow though then that vasculopathy is a cause of diminished cEPCs in Sickle cell disease. Increased consumption of cEPCs at sites of injury concomitantly induces depletion of cEPCs in peripheral blood (Figure $4)$.

The loss of CD133 during homing of the EPCs could be responsible for this trend. CD133, which is expressed on hematopoietic stem cells is absent on mature endothelial cells and monocytic cells [21].

CD133 are lost as early cEPCs differentiate into late or matured endothelial progenitor cells, eventually becoming Circulating endothelial cells (CECs) to replace the shed endothelial cells of the lining of the endothelium (Figure 5) [21]. This highly chemotactically regulated mechanism of differentiation and repair provides a novel mode to understand the diminished \%EPCs in peripheral circulation. Analysis of results showed that there was significant increase in the number of matured EPCs in patients in the painful crisis state as compared to those of steady state (Figure 2). A recent study conducted by Van Beem RT and others [22] at the Landsteiner Laboratory, Amsterdam, showed that EPC counts were comparable between controls $(0$; range, $0-1.1$ cells $/ \mathrm{ml})$ and patients $(0$; range, $0-0$ cells $/ \mathrm{ml})$ in asymptomatic state, but were significantly higher during painful crisis (41.7; range, $0-186$ cells $/ \mathrm{ml} ; \mathrm{p}<0.05$ ).

The slightly higher EPC count during painful crisis was only true with the growth factor-induced or late circulating EPCs. There was no significant difference in levels of immature \%EPCs. The higher EPC counts during painful crisis might indicate a role for EPC mobilization in re-endothelialization.

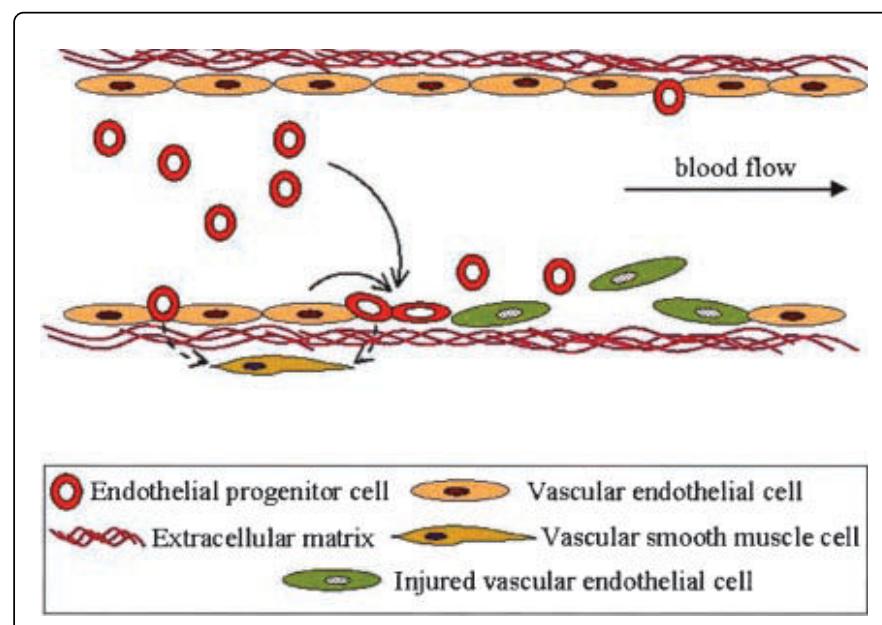

Figure 4: Vasculature showing that EPCs may contribute to the repair of injured vessels [16].

Results showed a strong positive correlation (Table 4) between percentage EPCs (using CD34+/VEGF-2+ as antibody) and total cholesterol in sickle cell patients. Interestingly, there was no such relationship found in healthy controls (Table 5). Increase or decrease in total cholesterol in SCD is therefore a positive index of EPCs count. Low total cholesterol recorded by an SCD patient presupposes a lower EPCs count also.

Higher total cholesterol could therefore stand for higher EPCs count. Sickle cell patients in crisis generally have a higher EPC than their asymptomatic counterparts [22]. It could therefore, though not sufficiently substantiated, be that all sickle cell patients suffering painful crisis also have high total cholesterol; and that higher total cholesterol could spell the onset (if not present) of painful crisis.

There was no significant relationship, however, between EPCs and each of Hemoglobin (Table 4) and White blood cell count (Table 4) in sickle cell patients. Hemoglobin and white blood cell counts are therefore not necessarily indices of percentage EPC counts. That notwithstanding, results also proved that White blood cell counts were significantly highest in sickle cell disease, especially the $\mathrm{Hb}$ SS genotype (Table 2) than in the rest of the other sub-groups ( $\mathrm{p} \leq 0.001$ ).

White blood cell counts give an indication of infection, inflammation or vascular perturbation but not necessarily influencing 
the percentage EPCs in the patient. WBCs and EPCs may therefore have independent needs for rescue recruitment to dysfunctional sites.

That EPCs have been mobilized does not necessarily depend on the recruitment of WBCs. In healthy controls, though, an inverse correlation was found between EPCs and WBC (Table 5). High WBC in non-SCD patients is commensurate to low EPCs count.

Well, this is in agreement with results of the research that non-SCD healthy individuals usually had a significantly lower WBC (Table 1) while at the same time they recorded a relatively higher EPCs count.

Again, SS genotype cases recorded the least Hemoglobin level (Table 1). This is an indication of anemia which is a common clinical feature of sickle cell disease. As part of Laboratory findings of SCD, Chestnut in 1994, found that $\mathrm{Hb}$ level of patients was usually 6-9 g/dl-low in comparison to symptoms of anemia. However, $\mathrm{Hb}$ level could not be a predictive measure of percentage EPCs. More so, there are several other non-sickle cell related anemic conditions or hemoglobinopathies.

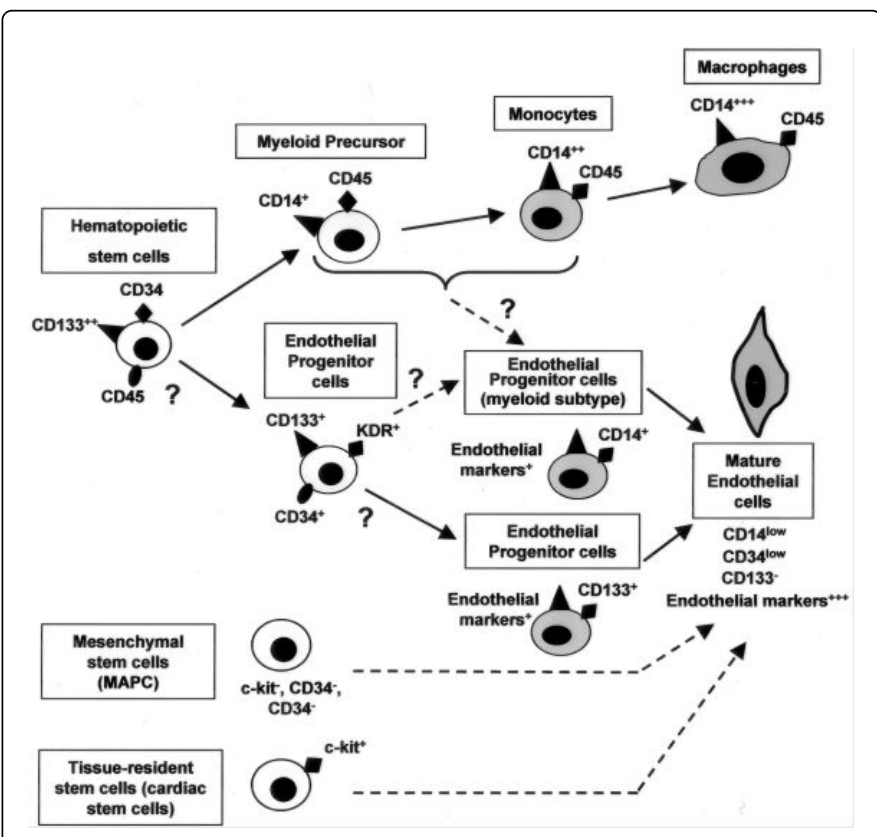

Figure 5: Origin and differentiation of endothelial progenitor cells. Scheme depicts the potential origin and differentiation of endothelial progenitor cells from hematopoietic stem cells and nonhematopoietic cells [21].

The Sickle cell anemia group (SS group) had a very high mean GGT; higher than the normal documented range (13-58) $\mu / \mathrm{L}$. In a recently published work by Oparinde and co [23], they found that elevated serum level of GGT in SCD during steady state is suggestive of increased severity of disease. This hence explains in another way why SS genotype is a more severe form of the disease.

Evidently, there was no significant correlation between EPCs and each of the liver enzymes, ALT, GGT and ALP. The implication being that increase or decrease in EPCs has no bearing upon levels of the liver enzymes. And yet in the Greece study, there was 39\% prevalence of acute vaso-occlusive involvement of the liver, a figure that is much higher than previously reported [24]. It follows then that Liver enzymes and the Liver at large may be involved in endothelial damage in sickle cell disease but not necessarily in relation to EPCs.

\section{Conclusion}

Sickle cell disease is underlined by vascular endothelial damage. Percentage EPCs is a measure of vascular injury in sickle cell disease. Number of cEPCs is diminished in sickle cell patients in comparison with healthy individuals. Percentage EPCs is higher in patients suffering painful vaso-occlusive crisis than their asymptomatic steady state counterparts. Generally, Sickle cell patients have higher white blood cell counts than healthy individuals. There is however no association between white blood cells counts and EPCs. Sickle cell patients have lower Hemoglobin levels as compared to normal healthy individuals. But this does not culminate in a strong inverse correlation between Hemoglobin levels and EPCs. Total cholesterol has a strong correlation with percentage EPCs. It is hence possible, though not substantiated that high total cholesterol is associated with painful crisis. Liver enzymes are not related to EPCs correlatively even though the liver may be involved in endothelial injury in sickle cell patients.

\section{Acknowledgement}

We are hugely indebted to the Department of Immunology of Noguchi Memorial Institute of Medical Research (NMIMR), Ghana for offering their flow cytometer instrument to be used for our experiments. University of Ghana, college of health sciences is recognized for providing funding for portions of the project. We thank Centre for Clinical Genetics at the Korle-Bu Teaching for allowing patients attending their clinic to be used as research participants. We thank the department of Chemical Pathology of University of Ghana medical school for being the parent institution where research was undertaken. We are grateful to the Chemical pathology unit of Central Lab, Korle-bu for assisting with Lipid profile experiments. We are thankful to Pastor Prince Nyarko for offering phlebotomy assistance during blood sampling of healthy control group. We are grateful to members of the Grace Victors ministry and members of the Lacommunity who partook in the project as healthy control group.

\section{References}

1. Chestnut D (1994) Perceptions of ethnic and cultural factors in the delivery of services in the treatment of sickle cell disease. J Health Soc Behav Pol 5: 236.

2. Sickle Cell Information Center (1997).

3. Abdulmalik O, Safo M, Chen Q, Yang J, Brugnara C, et al. (2005) 5hydroxymethyl-2-furfural modifies intracellular sickle haemoglobin and inhibits sickling of red blood cells. Brit J Haematol 128: 552-561.

4. Konotey Ahulu FID (1991) The sickle cell disease patient, 1st edition. Macmillan education LTD. London and Basinsgtoke 12: 317-324.

5. Vinay K, Abbas AK, Fausto N (2005) Robbins and Cotran Pathologic basis of disease, New Delhi, India 628-636.

6. Anthony R (2003) Endothelial progenitor cells New Engl J Med 348: 581-582.

7. Reyes M, Dudek A, Jahagirdar B, Koodie L, Marker PH, et al. (2002) Origin of endothelial progenitors in human postnatal bone marrow. J Clin Invest 109: 337-346.

8. Asahara T, Murohara T, Sullivan A, Silver M, Zee VDR, et al. (1997) Isolation of putative endothelial progenitor cells for angiogenesis. Science 275: 964-967.

9. Rafii S, Lyden D (2003) Therapeutic stem and progenitor cell transplantation for organ vascularisation and regeneration. Nat Med 9: 702-712. 
Citation: Osa-Andrews B, Asare-Anane H, Oppong SY, Nyarko AK, Kpentey G, et al. (2017) Role of Circulating Endothelial Progenitor Cells in Micro Vascular Damage in Sickle Cell Patients. J Blood Disord Transfus 8: 389. doi:10.4172/2155-9864.1000389

Page 8 of 8

10. Gill M, Dias S, Hattori K, Rivera ML, Hicklin D, et al. (2001) Vascular trauma induces rapid but transient mobilisation of VEGFR-2+, AC133+ endothelial precursor cells. Circ Res 88: 167-174.

11. Lyden D, Hattori K, Dias S, Costa C, Blaikie P, et al. (2001) Impaired recruitment of bone marrow derived endothelial and haematopoietic precursor cells blocks tumor angiogenesis and growth. Nat Med 7: 1194-1201.

12. Lin Y, Weisdorf DJ, Solovey A, Hebbel RP (2000) Origins of circulating endothelial cells and endothelial outgrowth from blood. J Clin Invest 105: 71-77.

13. Peichev M, Naiyer AJ, Pereira D, Zhu Z, Lane WJ, et al. (2000) Expression of VEGFR-2 and AC133 by circulating human CD34+ cells identifies a population of functional endothelial precursors. Blood 95: 952-958.

14. Hebbel RP, Vercellortti GM (1997) The endothelial biology of sickle cell disease. J Lab Clin Med 129: 288-293.

15. Dacie JV, Lewis SM (1991) Practical Hematology 7th Edition Edinburgh, Churchill Livingstone.

16. Hristov Mihail, Wolfgang E, Weber PC (2003) Endothelial progenitor cells mobilization, differentiation, and homing. Arterioscler Thromb Vasc Biol 23: 1185-1189.

17. George DF, Sampol J (2000) Circulating endothelial cells in vascular disorders: new insights into an old concept. Eur J Haematol 65: 215-220.
18. Liao JC (2002) Blood feud: Keeping hemoglobin from nixing NO. Nature Med 8: 1350-1351.

19. Morris CR (2008) Mechanisms of vasculopathy in sickle cell disease and thalassemia. Hematology 1: 177-185.

20. Hill JM, Zalos G, Halcox JPJ, Schenke WH, Waclawiw MA, et al. (2003) Circulating endothelial progenitor cells, vascular function, and cardiovascular Risk. N Engl J Med 348: 593-600.

21. Carmen U, Dimmeler S (2004) Endothelial progenitor cells characterization and role in vascular biology. Circ Res 95: 343-353.

22. Beem VRT, Nur E, Zwaginga JJ, Landburg PP, Beers VEJ, et al. (2009) Elevated endothelial progenitor cells during painful sickle cell crisis. Hematol 37:1054-1059.

23. Oparinde DP, Oghagbon EK, Okesina AB, Olatunji PO, Ojuawo AO (2006) Role of hepatic enzymes in the biochemical assessment of severity of sickle cell anaemia. Trop Gastroenterol 118-121.

24. Koskinas J, Manesis EK, Zachharakis GH, Galiatsatos N, Sevastos N, et al (2007) Liver involvement in acute vaso-occlusive crisis of sickle cell disease: prevalence and predisposing factors. Scand J Gastroenterol 42: 499-507. 